PONTIFÍCIA UNIVERSIDADE CATÓLICA DO RIO DE JANEIRO

Crescimento das Corretoras Independentes no Mercado Financeiro Brasileiro

Gilberto Dias de Azevedo

Trabalho de Conclusão de Curso

Centro de CIÊNCIAS SOCIAIS - CCS

DEPARTAMENTO de AdMINISTRAÇÃo

Graduação em Administração de Empresas 


\title{
Crescimento das Corretoras Independentes no Mercado Financeiro Brasileiro
}

\author{
Trabalho de Conclusão de Curso
}

Trabalho de Conclusão de Curso, apresentado ao programa de graduação em Administração da PUC-Rio como requisito parcial para a obtenção do título de graduação em Administração.

Orientadora : Liana Ribeiro dos Santos, PhD 


\section{Agradecimentos}

Primeiramente, agradeço aos meus familiares, especialmente a meus pais, pelas oportunidades de estudo, pela ajuda e pelo incentivo que me deram em todos estes anos em que estive na faculdade.

Aos amigos e colegas que fiz durante a faculdade, que tornaram estes anos mais divertidos e me ajudaram com as dificuldades durante o curso. Foram memórias inesquecíveis e amigos que ficarão para a vida toda.

Agradeço a minha orientadora Liana Ribeiro pelo suporte que me deu durante todo o semestre, com seus comentários que me auxiliaram bastante na confecção desta pesquisa. 


\section{Resumo}

Dias Azevedo, Gilberto. Crescimento das Corretoras Independentes no Mercado Financeiro Brasileiro. Rio de Janeiro, 2019. Número de páginas 32p. Trabalho de Conclusão de Curso - Departamento de Administração. Pontifícia Universidade Católica do Rio de Janeiro.

Este trabalho tem o objetivo de mostrar se de fato as corretoras de valores independentes têm aumentado sua participação no mercado financeiro brasileiro e o que tem feito para isso. A metodologia utilizada foi uma pesquisa exploratória de categoria quantitativa. Os resultados da pesquisa indicaram que as taxas cobradas pelas corretoras independentes são sensivelmente menores que as cobradas pelas corretoras ligadas a grandes bancos. Mostraram, também, que as corretoras analisadas estão crescendo em número de clientes ativos e valores sob custódia. Quanto aos entrevistados, a maioria acredita que menores taxas para investir é o fator mais importante na hora de escolher a corretora. Além disso, as carteiras de ações sugerida pelas corretoras independentes tiveram melhor rentabilidade do que a das corretoras ligadas aos grandes bancos.

Palavras-chave: Corretoras, Bancos, Investimentos, Ações, Carteira 


\section{Abstract}

Dias Azevedo, Gilberto. Growth of Independent Brokers in the Brazilian Financial Market. Rio de Janeiro, 2019. Number of pages 32p. Trabalho de Conclusão de Curso - Departamento de Administração. Pontifícia Universidade Católica do Rio de Janeiro.

This article has the objective to show if the independent brokers are really increasing their participation in the Brazilian financial market and what they are doing to achieve it. The used method was an exploratory research of quantitative category. The research results showed us that the independent brokers charge us significantly lower than the ones charged by brokers connected to Banks. They also showed that the analyzed brokers are growing in number of active clients and value under custody. About the interviewees, the most part of them believes that lower taxes to invest is the main reason to choose your broker. Also, the brokers suggested stock portfolio had a better profitability than the brokers linked to the big Brazilian banks.

Keywords: Brokers, Banks, Investments, Stocks, Portfolio 


\section{Sumário}

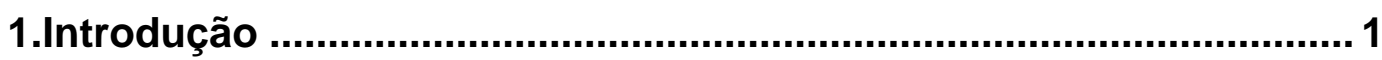

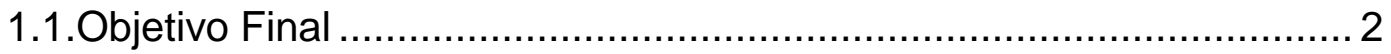

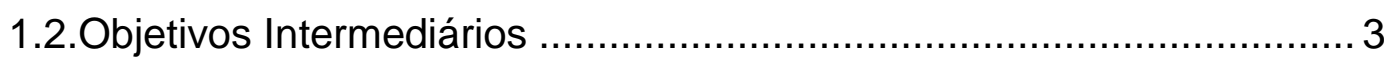

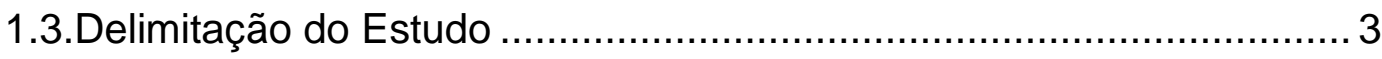

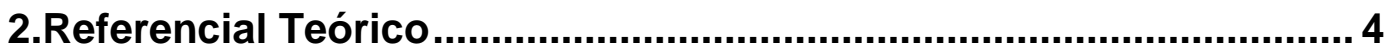

2.1.Comissão de Valores Mobiliários .......................................................... 4

2.2.Corretoras de Títulos e Valores Mobiliários ........................................ 4

2.2.1. Corretoras de bancos $x$ Corretoras independentes ............. 5

2.3.Produtos Financeiros ......................................................................... 7

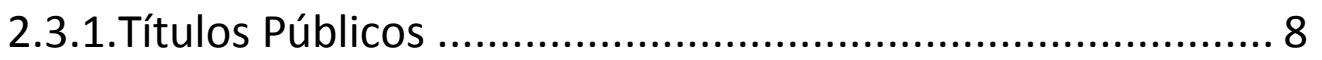

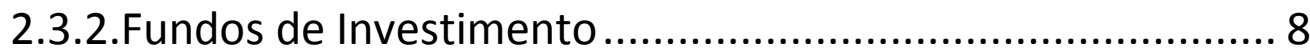

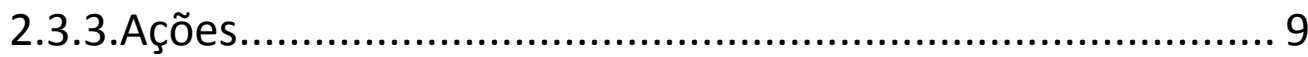

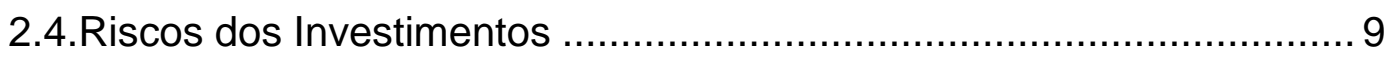

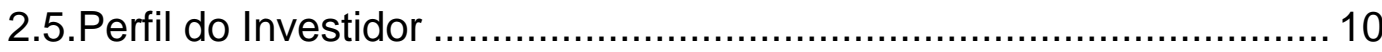

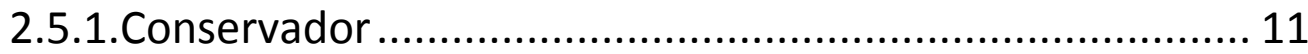

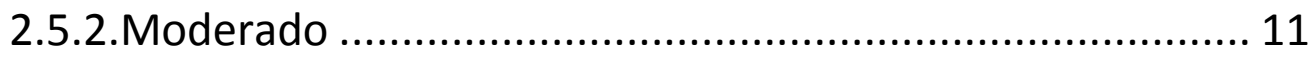

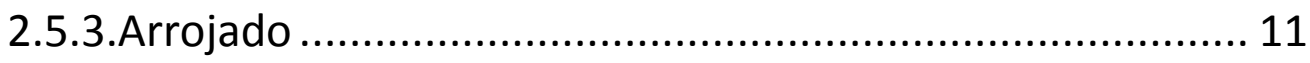

3.Métodos e procedimentos de coleta e análise de dados ................ 13

3.1. Métodos de pesquisa utilizados ..................................................... 13

3.2.Procedimentos e instrumentos de coleta de dados............................ 14

3.3. Formas de análise dos dados coletados para o estudo ..................... 15

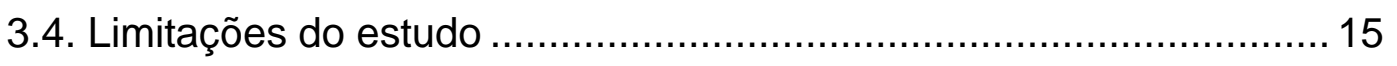

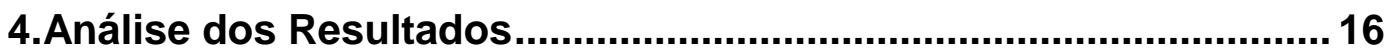

4.1.Descrição e análise dos resultados da pesquisa documental ............. 16

4.1.1. Rentabilidade das Carteiras Sugeridas............................ 17

4.2. Descrição da amostra e do perfil dos respondentes ......................... 18

4.2.1. Nível de Conhecimento em investimentos ...................... 19

4.2.2. Tipo de Instituição financeira para investir ....................... 21 
4.2.3. Rentabilidade Carteira dos respondentes........................ 22

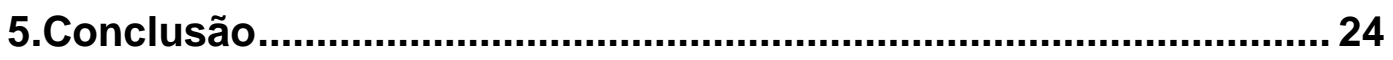

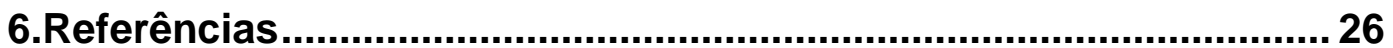

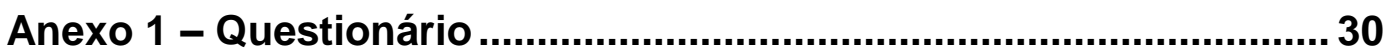




\section{Lista de Gráficos}

Gráfico 1- Brasileiros que investem na Bolsa. Fonte: B3/2019 ................ 2

Gráfico 2 - Perfil Investidor. Fonte: Adaptação Anbima/2017 ................ 12

Gráfico 3 - Motivos escolha Instituição Financeira para investir..............22 


\section{Lista de Tabelas}

Tabela 1 - Taxas cobradas pelas Corretoras .................................... 16

Tabela 2 - Clientes Ativos x Valor Sob Custódia nas Corretoras

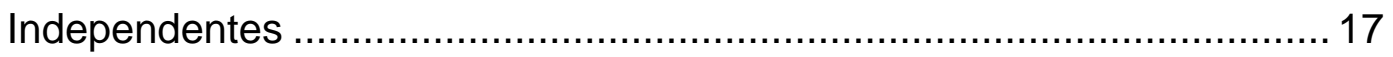

Tabela 3 - Rentabilidade Carteira de ações Instituições Financeiras...... 18

Tabela 4 - Avaliação Instituições Financeiras .................................... 18

Tabela 5 - Respondentes por faixa etária …................................. 19

Tabela 6 - Respondentes por faixa etária, renda e escolaridade ............ 19

Tabela 7 - Perfil de Risco dos respondentes ..................................... 20

Tabela 8 - Nível de Conhecimento x Objetivo ao investir.......................20

Tabela 9 - Tipo de Instituição financeira x Perfil de Investimento............21 21

Tabela 10 - Nível de Conhecimento x Tipo de Instituição Financeira ......21

Tabela 11 - Rentabilidade Carteiras Corretoras Independentes .............. 23 


\section{Introdução}

Para a maior parte da população brasileira, investir ainda é uma realidade distante. Segundo dados provenientes de pesquisa encomendada pela Associação Brasileira das Entidades dos Mercados Financeiro e de Capitais - Anbima (2018) mais da metade dos brasileiros não investe. Efetivamente, apenas $42 \%$ dos brasileiros tinham algum saldo aplicado em produtos de investimento. Ainda segundo a pesquisa, o brasileiro continua a ter preferência pela caderneta de poupança, priorizando segurança ao retorno.

Segundo dados da CVM (2018), praticamente sete em cada dez brasileiros, que dispõem de recursos para investir, optam pela tradicional caderneta de poupança $(69,3 \%$, diminuindo para $60,7 \%$ entre os mais jovens), enquanto apenas $5 \%$ fazem investimentos em ações na Bolsa de Valores.

Mesmo investindo pouco e preferindo a poupança, os investimentos financeiros da população brasileira, segundo dados da Anbima (2019), tiveram um aumento de $2,4 \%$ em relação ao fim de 2018. Ainda segundo a Anbima os aportes em ativos de renda variável cresceram na comparação ao mesmo período do ano passado: no segmento de varejo houve aumento de $27,4 \%$ nas aplicações em fundos de ações e de 15,6\% no investimento direto em ações.

Outro fato que chamou atenção, segundo dados da B3 (2019), foi que o número de investidores ativos no mercado de ações no Brasil deu um salto de 60\% em maio de 2019, para mais de 1,1 milhão de pessoas físicas. O gráfico abaixo mostra o número de investidores pessoas física na Bolsa de Valores. 


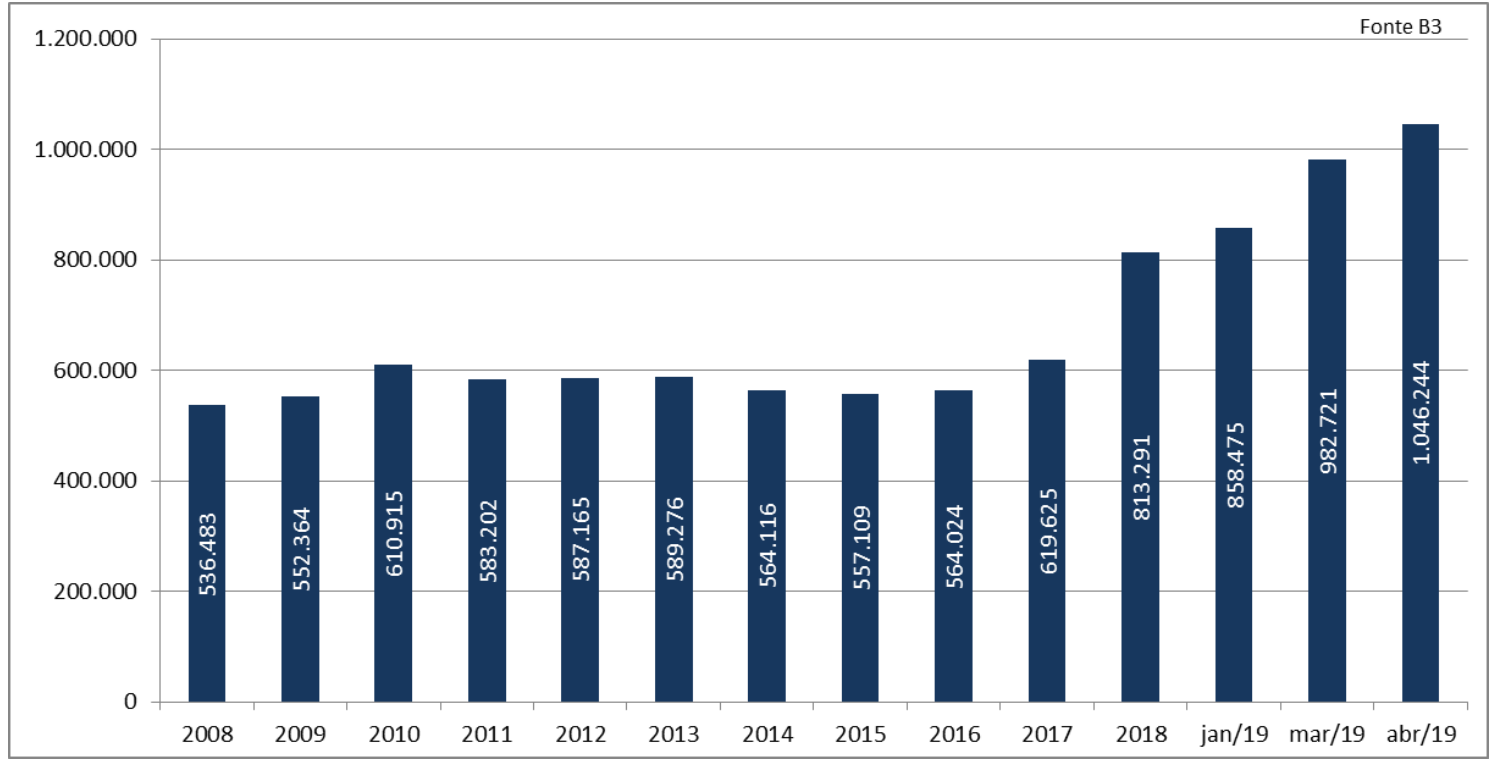

Gráfico 1- Brasileiros que investem na Bolsa. Fonte: B3/2019

As pessoas estão mudando a sua forma de encarar investimentos, querendo diversificar. Segundo Paiva (2019), diretor de Relacionamento com Clientes Brasil da B3, a maior participação das pessoas físicas na bolsa de valores, deve-se entre outros, ao cenário macroeconômico mais favorável, a taxa básica de juros (Selic) em $5 \%$, com tendência de queda, e ao papel exercido pelas corretoras, oferecendo boas alternativas em diversas aplicações. Para ele, as pessoas estão percebendo outros instrumentos financeiros que trazem retornos melhores do que a poupança.

Segundo Cutait (2019), editora do Infomoney, um levantamento da XP com base em dados da Economática, mostra que as corretoras independentes do Brasil têm hoje uma participação de 34\% no patrimônio total do setor. Em 2015 esta fatia era de 31\%. E, depois de sofreram resgates maiores que aportes em 2015 na soma das classes de ativos, as gestoras independentes tiveram saldo líquido positivo em todos os anos desde então, ou seja, captaram mais recursos do que perderam.

Neste cenário, segundo Mallman (2015), as corretoras independentes precisam se destacar no mercado, e o sucesso dos investimentos e a satisfação de seus clientes são pontos essenciais para conquistar reconhecimento.

\subsection{Objetivo Final}

O objetivo deste trabalho é mostrar como as corretoras independentes vêm ganhando espaço no mercado brasileiro, conquistando mais investidores, entre os que já investem e os que ainda não investem, com todos os perfis de risco. 


\subsection{Objetivos Intermediários}

Para atingir o objetivo final, os seguintes objetivos específicos foram determinados:

- Identificar as principais características das corretoras independentes e das ligadas a bancos comerciais;

- Levantar as opções de investimentos oferecidas pelas corretoras independentes;

- Comparar o desempenho das carteiras de ações oferecidas pelas corretoras independentes com as oferecidas pelas corretoras ligadas a bancos comerciais.

\subsection{Delimitação do Estudo}

Como existe um grande número de corretoras, esta pesquisa irá utilizar informações das principais corretoras ligadas aos grandes bancos privados (Bradesco, Itaú e Santander) e das corretoras independentes XP Investimentos, Rico CTVM, Easynvest e Ativa Investimentos. 


\section{Referencial Teórico}

\subsection{Comissão de Valores Mobiliários}

A Comissão de Valores Mobiliários (CVM) foi criada em 07/12/1976 pela Lei 6.385/76, com o objetivo de fiscalizar, normatizar, disciplinar e desenvolver o mercado de valores mobiliários no Brasil (CVM, 2019).

Tem por princípio básico defender os interesses do investidor, especialmente o acionista minoritário, e o mercado de valores mobiliários em geral, entendido como aquele em que são negociados títulos emitidos pelas empresas para captar, junto ao público, recursos destinados ao financiamento de suas atividades (CVM, 2019).

Dentre suas principais atribuições estão:

- Assegurar o funcionamento eficiente e regular dos mercados da bolsa e de balcão;

- Proteger aqueles que possuem algum tipo de valor mobiliário e os demais investidores contra as emissões irregulares, atos considerados ilegais de alguns administradores e acionistas controladores de companhias abertas, ou de administradores de carteira;

- Estimular a expansão e o bom funcionamento do mercado de ações;

- Combater fraudes ou manipulações que simulem condições artificiais de demanda, oferta ou preço dos valores mobiliários comumente negociados no mercado;

- Estimular a formação de poupança e sua aplicação em valores mobiliários;

- Fornecer o acesso a informações sobre os valores mobiliários negociados e sobre as companhias que os tenham emitido.

\subsection{Corretoras de Títulos e Valores Mobiliários}

As corretoras de títulos e valores mobiliários (CTVM) atuam na negociação de títulos e valores mobiliários entre investidores e tomadores de recursos. As corretoras e distribuidoras, na atividade de intermediação, oferecem serviços como plataformas de investimento pela internet (home broker), consultoria financeira, clubes de investimentos, administração e custódia de títulos e valores mobiliários dos clientes, entre outros. $\mathrm{Na}$ remuneração pelos serviços, essas instituições podem cobrar comissões e taxas. (BCB, 2019) 
Segundo Mallman (2015), Corretoras de valores são instituições financeiras voltadas para investimentos. O principal papel de uma corretora é atuar como intermediária na compra e venda de ativos financeiros.

Ainda segundo Mallmann (2015), as corretoras de valores necessitam de autorização prévia do Banco Central do Brasil para serem constituídas, estando sujeitas à supervisão do próprio $B C B$, da CVM e da B3, empresa resultante da união entre a BM\&FBOVESPA e a Cetip.

A B3, através do Programa de Qualificação Operacional (PQO), avalia e reconhece a qualidade dos serviços prestados pelas corretoras de valores, que atuam nos mercados por ela administrados (B3, 2019).

\subsubsection{Corretoras de bancos $\mathrm{x}$ Corretoras independentes}

Segundo Mallmann (2015), as corretoras de valores podem tanto ser ligadas a um banco comercial, quanto independentes, neste caso sem relação com qualquer banco.

Segundo Martins (2019) tanto as instituições independentes ou ligadas a grandes bancos facilitam o acesso a um conjunto cada vez maior de aplicações financeiras, incluindo títulos públicos do Tesouro Direto, Certificado de Depósito Bancário (CDB), fundos de investimento e ações. Além do cardápio de investimentos, muitas oferecem serviços de consultoria, materiais educativos, simuladores e relatórios sobre mercados e companhias com ações negociadas na bolsa.

Segundo Mallmann (2017) na hora de optar por investir em corretoras de grandes bancos ou independentes, deve-se verificar se a corretora possui selo de certificação PQO. Para o investidor pessoa física, o selo mais importante é o Retail Broker. A corretora que possui o selo Retail Broker é avaliada nos seguintes indicadores:

- Oferta de serviços de assessoria e plataforma eletrônica de negociação de produtos financeiros, especializados em investidores pessoas físicas;

- Diversificação de produtos, conteúdo educacional e de alternativas de investimento;

- Oferta de ferramentas de negociação de tecnologia móvel e plataformas eletrônicas voltadas a investidores;

- Disponibilização de diferentes canais de relacionamento e atendimento de clientes.

Segundo Wawrzeniak (2017), os principais pontos a serem avaliados e comparados na hora de escolher a corretora são: custo, atendimento, ferramentas e serviços oferecidos.

Os valores cobrados podem variar bastante entre as corretoras, sendo os principais: 
- Taxa de corretagem: é valor cobrado por cada negociação de compra e venda de ativos na Bolsa de Valores. Pode ser um valor fixo, independente do volume operado ou variável, em que é cobrado um percentual sobre o monte da operação acrescido de um valor fixo.

- Taxa de custódia: é o custo referente a guarda dos ativos, portanto ela é cobrada somente quando o investidor possuir alguma posição em ativos de renda variável naquele mês. Os valores de mercado para a custódia também variam bastante. Algumas corretoras de valores não cobram, outras cobram apenas se não houver ordens executadas no mês e outras cobram independente disso.

- Taxa para o Tesouro Direto: é cobrada pela corretora para intermediar as operações de compra e venda de títulos públicos do Tesouro Direto. Esta taxa é uma porcentagem do montante investido e geralmente cobrada anualmente. Pode variar de $0 \%$ a $2 \%$.

Para Wawrzeniak (2017), o atendimento aos clientes é outro ponto importante, devem ser avaliados a disponibilidade, a agilidade dos profissionais, os canais de atendimento que a corretora oferece para atender seus clientes. Enquanto algumas corretoras de valores são bastante acessíveis, com diversos canais de comunicação e uma equipe bem treinada, outras são difíceis de entrar em contato.

Ainda segundo Wawrzeniak (2017), outro ponto importante a ser avaliado são os serviços e as ferramentas oferecidas pelas corretoras. Dentre os principais estão:

- Home broker. Algumas corretoras de valores oferecem o envio de ordens básico, enquanto outras oferecem ferramentas gráficas, indicadores, acompanhamento de trades ao vivo, chat com analistas. A tecnologia usada varia, podendo afetar a velocidade com que as ordens são executadas;

- Aplicativo mobile: Algumas corretoras de valores oferecem aplicativos para smartphones e tablets, que podem ser gratuitos ou cobrados a parte;

- Variedade de produtos disponíveis;

- Relatórios de análises de mercado;

- Recomendações de investimento que podem ou não serem personalizadas;

- Educacional: Algumas corretoras oferecem cursos presenciais, palestras e materiais educacionais gratuitos. 


\subsection{Produtos Financeiros}

Existe no mercado uma grande variedade de produtos financeiros, que oferecem diferentes rentabilidades e diferentes níveis de risco, como investimentos em renda fixa, fundos de investimento, previdência e renda variável.

Segundo Rico (2019), as aplicações em renda fixa são investimentos nos quais podemos ter maior previsibilidade do resultado da aplicação. $O$ autor explica que nas aplicações pré-fixadas a taxa de juros é predeterminada, ou seja, é determinada no momento da contratação. Já nas aplicações pós-fixadas a taxa de juros é apurada após determinado período e é vinculada a algum indicador, como a taxa Selic, CDI, IPCA, dentre outros. A Taxa Selic é a taxa básica de juros definida pelo governo e o CDI - Certificado de Deposito Interfinanceiro é a taxa com valor próximo ao da Selic, utilizada para empréstimos entre instituições financeiras de curto prazo. O IPCA é o índice mais utilizado para medir a inflação no Brasil.

O autor ainda define um terceiro tipo de aplicação de renda fixa, além da pré e da pósfixada, existe a rentabilidade híbrida, onde possui parte fixa e parte variável, como por exemplo, os títulos que rendem IPCA+5\%. Geralmente esses investimentos possuem como indexadores, os índices de inflação, como IPCA e IGP-M, portanto os rendimentos variam com o tempo.

Todos esses investimentos são títulos de créditos emitidos por alguma organização como o Governo (Tesouro Direto), bancos (CDBs, LCls e LCAs) ou financeiras (LCs).

Diferente da renda fixa onde temos grande previsibilidade de nossas aplicações, devido à baixa volatilidade desse tipo de investimento, a renda variável reúne investimentos com oscilações imprevisíveis, determinadas por diversos fatores difíceis de controlar. (RICO, 2019)

Segundo Rico (2019), esses ativos, por terem mais risco, também têm mais chances de trazer uma rentabilidade maior que a renda fixa. Essa é uma lei do mercado. Quanto maior o risco, maior o retorno esperado. É preciso equilibrar esses fatores na hora de escolher um investimento. Exemplos de renda variável são ações, opções e derivativos na bolsa de valores, fundos de investimento de ações e multimercados, entre outros. 


\subsubsection{Títulos Públicos}

São ativos de renda fixa, emitidos pelo Governo Federal com o objetivo de captar recursos para o financiamento da dívida pública e das atividades governamentais (educação, saúde etc) (CVM, 2019).

Há uma grande variedade de títulos públicos, podendo ser prefixados ou pós-fixados e tem rentabilidade diária, via recompra pelo Tesouro Nacional. A recompra é realizada pelo preço de mercado na data do saque do dinheiro, o que pode afetar o rendimento (ANBIMA, 2019).

Para investir em títulos públicos, os riscos são baixos. Os principais tipos de risco destes títulos são os riscos de crédito, associado ao risco do governo não ter capacidade de pagamento para devolver o valor devido, o risco de mercado, ligado principalmente à variação da Selic e do IPCA e o risco de liquidez, ligado ao saque antecipado. De qualquer modo, em qualquer país, o mercado considera que o governo oferece o menor risco de crédito (ANBIMA, 2019).

As grandes vantagens destes títulos são a garantia de crédito do governo, a falta de carência para saque antecipado e o investimento inicial acessível (ANBIMA, 2019).

\subsubsection{Fundos de Investimento}

Um fundo é organizado sob a forma de condomínio e seu patrimônio é dividido em cotas, cujo valor é calculado diariamente por meio da divisão do patrimônio líquido pelo número de cotas do fundo (CVM, 2019).

É um tipo de investimento coletivo, organizado por instituições financeiras, no qual se compra uma cota do fundo e recebe a valorização dela no investido. Normalmente não tem prazo de vencimento e costumam ter liquidez diária. O investimento mínimo costuma variar conforme a instituição e o fundo e o risco deste investimento está relacionado à carteira de ativos comprados pelo fundo (ANBIMA, 2019).

$\mathrm{Na}$ classificação da ANBIMA, os fundos são divididos pelos tipos de ativo em que investem:

- Fundo de Renda Fixa: Aplica em papéis de renda fixa, como títulos públicos e privados.

- Fundo de Renda Variável: Aplica em papéis de renda variável, como ações. 
- Fundo Multimercado: Pode aplicar parte em renda fixa, parte em renda variável e parte em moedas.

- Fundo Cambial: Aplica em papéis atrelados à variação de preços de moedas, como dólar ou euro.

\subsubsection{Ações}

O Mercado de Ações representa, para as sociedades anônimas, o meio de captação de recursos necessários ao seu desenvolvimento patrimonial, no qual vende a participação no seu respectivo patrimônio líquido e assume o compromisso de remunerar os seus acionistas em função do capital nela aplicado, e de seus futuros resultados (FORTUNA, 2014).

É um tipo de investimento oferecido pelas empresas, no qual os investidores participam dos lucros/prejuízos da companhia em que investem. Não há prazo de vencimento podendo ser negociadas a qualquer momento e quanto à liquidez, depende do interesse do mercado naquele papel. A remuneração se dá pela venda da ação por valor superior ao da compra e pelo pagamento de dividendos, parcela que o acionista recebe dos lucros da empresa (ANBIMA, 2019).

Os riscos deste tipo de investimento são o risco da empresa falir ou passar por alguma dificuldade, tendo sua ação desvalorizada, o risco associado à oscilação dos preços das ações por variações da economia que possam afetar a empresa e o rico de liquidez, relacionado à dificuldade de encontrar um comprador disposto a pagar o valor desejado (ANBIMA, 2019).

A grande vantagem deste tipo de investimento é a possibilidade potencial de retorno a longo prazo. As desvantagens estão associadas ao retorno esperado, uma vez que quando o potencial de ganho é mais alto, o risco também tende a aumentar, a complexidade do investimento, exigindo mais conhecimento do investidor para uma gestão consciente das suas aplicações e a liquidez, uma vez que é necessário um comprador disposto querendo comprar a ação (ANBIMA, 2019).

\subsection{Riscos dos Investimentos}

Muitas vezes os objetivos projetados para o investimento podem não ser alcançados. Quando é feito um investimento, tem-se inicialmente uma expectativa da sua rentabilidade, ou seja, um retorno esperado do investimento. Há sempre alguma incerteza quando vamos 
realizar um investimento e o risco pode ser considerado como a medida dessa incerteza em relação à rentabilidade de um investimento (CVM, 2019).

Segundo a Anbima (2019), todo o investimento tem um risco e o mercado de investimentos está sujeito a três principais tipos de risco: risco de mercado, risco de crédito e risco de liquidez.

O Risco de Mercado decorre das condições da economia, influenciando o investimento de forma positiva ou negativa. Além disso, a capacidade de pagamento do emissor do título (ou o lucro desse emissor) também pode variar por conta das condições da economia (CVM, 2019).

O Risco de Crédito está relacionado à capacidade de pagamento da instituição na qual o investimento está sendo feita (ANBIMA, 2019).

O risco de liquidez está diretamente relacionado a facilidade de poder resgatar ou transferir o investimento (CVM, 2019).

Segundo a CVM (2019) o risco operacional, decorrente da possibilidade de ocorrência de perdas resultantes de falhas causadas por problemas nos sistemas da empresa, por falhas humanas ou por má administração dos recursos do emissor.

Segundo a CVM (2019) existem no mercado diversos títulos e valores mobiliários sendo negociados com retornos esperados diferentes e riscos diferentes. Quanto maior for o risco de um investimento, maior deverá ser o seu retorno esperado. Na hora de investir é importante que risco e retorno sejam analisados conjuntamente.

Ainda segundo a CVM (2019), uma das formas de diminuir o risco é a diversificação de investimentos, ou seja, procurar ter diferentes tipos investimentos. Apesar disso, a diversificação não é capaz de eliminar todo o risco de um investimento. Existe o risco sistêmico ou não diversificável, que é aquele que afeta a economia de uma forma geral.

\subsection{Perfil do Investidor}

Segundo Assaf Neto (2015), os mercados financeiros oferecem diversos instrumentos financeiros com variados níveis de risco e retorno, o que possibilita a adequação das alternativas aos diferentes perfis de risco dos investidores, tendo o investidor uma grande variedade de opções de investimentos, de acordo com o perfil de cada investidor.

Segundo Wiltgen (2016), com base no perfil do investidor, conhecendo o quanto o investidor está propenso a correr riscos, suas expectativas de retorno esperado, é possível recomendar os investimentos mais adequados.

Geralmente, são três os perfis de risco: conservador, moderado e arrojado (ANBIMA, 2019). 


\subsubsection{Conservador}

O investidor conservador tem baixa tolerância a risco, privilegia segurança, liquidez e procura diminuir o risco de perdas, mesmo que sua rentabilidade seja menor (CVM, 2019).

Segundo levantamento do BB (2019), o perfil conservador prioriza a segurança, sendo recomendável manter um percentual maior de investimentos em produtos de baixo risco, admitindo-se uma pequena parcela em produtos que ofereçam níveis de riscos diferenciados, com objetivo de atingir ganhos no longo prazo.

Segundo a Anbima (2019), o perfil conservador, abrange pessoas com pouca tolerância ao risco, tendo como maior objetivo a preservação dos valores aplicados. Perfil voltado para aplicações em renda fixa e títulos públicos.

Investimentos como Poupança, Títulos Públicos e Fundos de Investimentos de Curto Prazo são mais compatíveis com este perfil de investidor (CVM, 2019).

Os mais conservadores devem aplicar até $10 \%$ na bolsa; os mais ousados podem investir $20 \%$.

\subsubsection{Moderado}

O investidor moderado procura um equilíbrio entre segurança e rentabilidade e aceita correr certo risco para que o seu dinheiro tenha um retorno um pouco maior (CVM, 2019).

De acordo com Wiltgen (2016), o investidor moderado assume risco um pouco maiores, buscando rentabilidade acima da média e aceita perdas controladas. Para ele o investidor com perfil moderado busca diversificar a sua carteira de investimentos, de modo que isso lhe traga segurança.

Segundo a Anbima (2019), o perfil moderado é representado por pessoas que que querem equilibrar melhor a relação entre risco e retorno, com maior tolerância a perdas, desde que moderadas, com maior chance de retornos mais altos no longo prazo. Perfil voltado para aplicações em fundos de renda fixa, multimercados, podendo aplicar pequena parte em ações.

Investimentos, como fundos de renda fixa, ações e debêntures, podem ser considerados para investidores com perfil moderado (CVM, 2019).

\subsubsection{Arrojado}


O investidor arrojado privilegia a rentabilidade e aceita riscos maiores para que seu investimento tenha um maior retorno (CVM, 2019).

Segundo Wiltgen (2016), o investidor agressivo assume riscos mais altos, buscando maiores rentabilidades e entende que a oscilação diária dos ativos é suavizada no médio/longo prazo.

Segundo a Anbima (2019), perfil arrojado opta por ganhar sempre mais, ainda que a possibilidade de prejuízo seja maior. Perfil sugere que o investidor pode aplicar a maior parte de seus recursos em fundos multimercados e ações.

Os Fundos Multimercado são exemplos de investimento mais compatíveis com investidores de perfil arrojado, uma vez que há muita liberdade na composição de suas carteiras e mais exposição ao risco em busca de maior rentabilidade. Os investimentos em ações, também, são recomendados para este perfil de investidor, que pode investir até $20 \%$ em ações. (CVM, 2019)

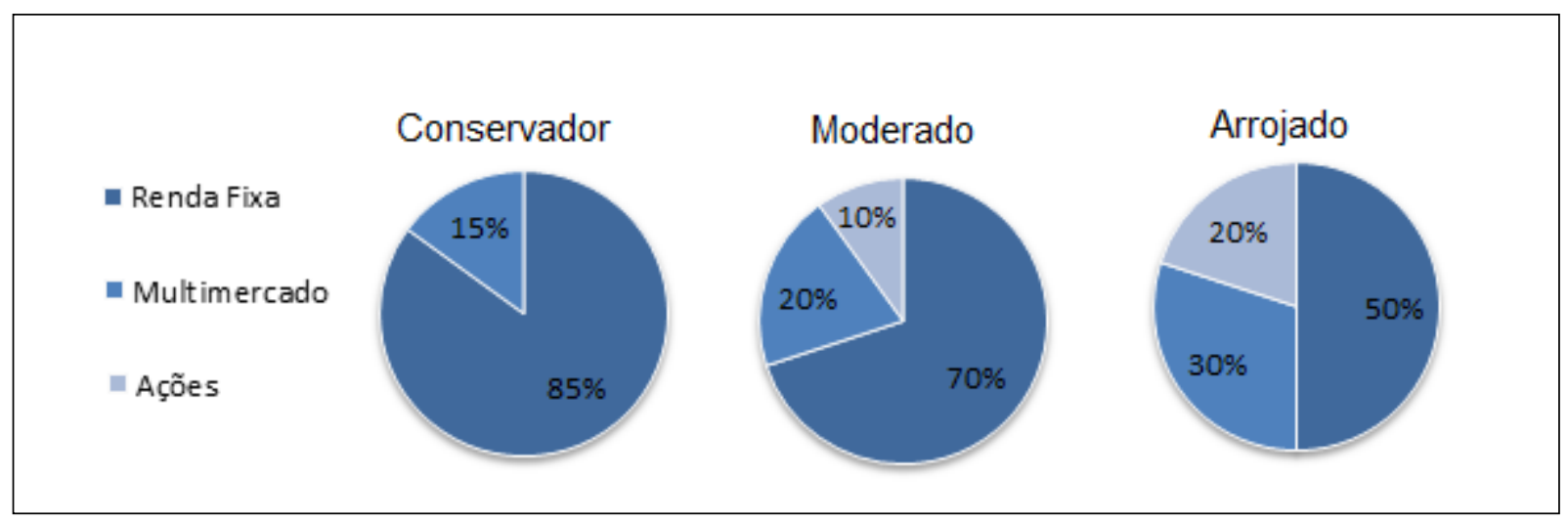

Gráfico 2 - Perfil Investidor. Fonte: Adaptação Anbima (2017) 


\section{Métodos e procedimentos de coleta e análise de dados}

Este capítulo traz informações sobre a forma como esta pesquisa foi realizada. Segundo Prodanov e Freitas (2013), o planejamento de uma pesquisa passa pela fase decisória, onde é feita a escolha do tema, a definição e a delimitação do problema da pesquisa, pela fase construtiva, onde se constrói um plano de pesquisa, que irá direcionar a execução da pesquisa propriamente dita e da fase redacional referente à coleta dos dados e informações obtidas na fase construtiva.

O presente capítulo está dividido em quatro seções que informam, sobre os métodos de pesquisa utilizados, sobre os procedimentos e instrumentos de coleta de dados utilizados no estudo, sobre as formas de análise dos dados coletados para o estudo e limitações do estudo.

\subsection{Métodos de pesquisa utilizados}

Foi realizada uma pesquisa descritiva, buscando identificar quais dados poderiam ser registrados, analisados e comparados para embasar a pesquisa. Segundo Gil (2008), as pesquisas deste tipo têm como principal objetivo descrever as características de determinada população ou fenômeno ou ainda estabelecer relações entre variáveis. Uma de suas peculiaridades está na utilização de técnicas padronizadas de coleta de dados, tais como o questionário e a observação sistemática.

Para Perovano (2014), o processo descritivo visa à identificação, registro e análise dos fatos. Neste tipo de pesquisa, após a coleta de dados, é realizada uma análise das relações entre as variáveis.

Inicialmente, houve uma pesquisa bibliográfica e documental. Para Gil (2008), pesquisas bibliográficas são feitas em livros ou artigos científicos, já a pesquisa documental é parecida com a bibliográfica, sendo que a diferença está na natureza das fontes, valendose de materiais que não receberam ainda um tratamento analítico, ou que ainda podem ser reelaborados de acordo com os objetos da pesquisa. Foram feitas pesquisas em jornais, livros, artigos acadêmicos, dissertações e monografias sobre temas relevantes ao assunto do estudo. Ainda foram feitas consultas aos sites da CVM, B3, Anbima, Banco Central. Além 
disso, foram feitas conversas informais com pessoas que trabalham nas corretoras independentes e na corretora do Banco Bradesco.

Posteriormente, foi realizada uma pesquisa de campo por meio de um questionário, caracterizando uma pesquisa quantitativa. Para Gil (2008), a pesquisa quantitativa considera que tudo pode ser quantificável, ou seja, traduzido em números, opiniões e informações para serem classificados e analisados, por meio de técnicas estatísticas. No caso dessa pesquisa, apenas técnicas de porcentagem foram utilizadas.

\subsection{Procedimentos e instrumentos de coleta de dados}

$\mathrm{Na}$ etapa de coleta de dados, já definido os dados que seriam comparados, foram analisados dados mais específicos sobre as principais Corretoras de Valores pesquisadas, com pesquisas aos sites das corretoras: Bradesco Corretora, Itaú Corretora, Santander Corretora, XP Investimentos, Rico, Easynvest, Clear CTVM e Ativa Investimentos , buscando informações sobre os principais custos cobrados pelas mesmas: taxa de corretagem, taxa de custódia e valor para operar no tesouro direto. Estes dados foram colocados em uma planilha para serem melhor visualizados e comparados.

No site de instituições de pesquisas como a Proteste e do buscador de investimentos Yubb, coletou-se informações sobre a variedade de produtos financeiros disponibilizados, os serviços oferecidos, a evolução do número de clientes, as taxas e rentabilidade obtidas, utilizando resultados de pesquisas já realizadas por estas instituições.

De posse das novas informações coletadas, um questionário online foi elaborado através do software Qualtrics Survey Software. Inicialmente, o questionário foi distribuído para 3 pessoas para verificar sua clareza, compreensão e aceitabilidade. Feito os ajustes necessários, foi distribuído através de redes sociais e e-mail para alunos da Pontifícia Universidade Católica (PUC - Rio), familiares, amigos de familiares, colegas de trabalho do autor e de familiares do autor.

O questionário aplicado, em anexo, teve 11 questões, sendo 3 sobre perguntas gerais relacionadas à idade, escolaridade e renda. As 8 perguntas restantes foram sobre investimentos. As primeiras perguntas sobre investimentos, procuraram identificar se o respondente investia, como ele avaliava seu conhecimento sobre investimentos, qual o seu principal objetivo ao investir, o tempo que desejava manter seus investimentos e o que faria se suas ações caíssem $20 \%$. Essas perguntas procuravam identificar o nível de risco que o respondente estava disposto a correr e o retorno desejado. As duas próximas perguntas foram mais específicas sobre as corretoras independentes. Foi perguntado sobre o tipo de 
instituição financeira que preferia para aplicar seu dinheiro e por quais motivos escolheu essas instituições. A última pergunta pedia que o respondente montasse sua carteira de investimentos indicando quantos \% do total da carteira alocaria em cada uma das opções de investimentos dadas.

\subsection{Formas de análise dos dados coletados para o estudo}

Os dados coletados através da pesquisa documental foram colocados em planilhas para que pudessem ser mais facilmente comparados. Já a coleta de dados, via questionário, teve 127 respondentes.

As perguntas do questionário foram na maioria múltiplo-escolha e objetivas, com apenas uma questão de preenchimento, procurando identificar os que investiam, nível de conhecimento sobre investimentos, se investiam através de corretoras independentes e o que era importante na hora de escolher a Corretora de Valores.

A partir da análise dos resultados, tanto dos dados da pesquisa documental, quanto das respostas do questionário, foi possível estabelecer uma relação destes dados com o que foi apresentado no referencial teórico.

\subsection{Limitações do estudo}

Com relação ao questionário, o fato de ser distribuído através de redes sociais ou email, faz com que algumas pessoas demorem a responder ou não respondam o questionário, prejudicando o tamanho da amostra. Como não há nenhum contato entre o autor e o respondente, as dúvidas que surgem relacionadas às questões, não podem ser esclarecidas.

Além disso o público selecionado para responder ao questionário, tem relação com o autor, gerando uma tendenciosidade, já que a amostra não foi aleatória, não tendo uma representatividade ampla. 


\section{Análise dos Resultados}

Este capítulo apresenta e descreve os resultados obtidos com a pesquisa. Além de estabelecer relações com os assuntos tratados no referencial teórico.

$\mathrm{Na}$ pesquisa documental, informações relacionadas as taxas cobradas pelas corretoras, aos serviços prestados, a variedade de produtos e a rentabilidade apareceram como importantes na escolha da corretora para investir e por isso foram abordados nas perguntas do questionário.

\subsection{Descrição e análise dos resultados da pesquisa documental}

Como mencionado no referencial teórico, as taxas cobradas podem variar bastante entre as corretoras. A tabela a seguir mostra a relação das taxas de corretagem e custódia cobrada pelas corretoras.

Tabela 1 - Taxas cobradas pelas Corretoras

\begin{tabular}{|c|c|c|}
\hline CORRETORAS & \multicolumn{2}{|l|}{ Taxas (Renda Variável) } \\
\hline Bancos & Corretagem à Vista & $\begin{array}{l}\text { Custódia } \\
\text { (Mensal) }\end{array}$ \\
\hline Bradesco & $\begin{array}{c}0,20 \% \text { sobre operações de até } R \$ 100 \text { mil } 0,10 \% \text { sobre } \\
\text { operações acima de } R \$ 100 \text { mil (corretagem mínima de } \\
R \$ 10 \text { por dia) }\end{array}$ & $\mathrm{R} \$ 14,99$ \\
\hline Itaú & $R \$ 10+0,3 \%$ por ordem para operação normal & $\mathrm{R} \$ 15,80$ \\
\hline Santander & $\mathrm{R} \$ 10,00+0,25 \%$ por ordem via home broker & $\mathrm{R} \$ 30,63$ \\
\hline \multicolumn{3}{|l|}{ Independentes } \\
\hline $\begin{array}{l}\text { Ativa } \\
\text { Investimentos }\end{array}$ & $\mathrm{R} \$ 15$ por ordem para ações operação normal & $\mathrm{R} \$ 9,80$ \\
\hline Clear CTVM & não cobra & não cobra \\
\hline Easynvest & 4,99 & não cobra \\
\hline Rico CTVM & $\mathrm{R} \$ 10$ para ações operação normal & não cobra \\
\hline $\mathrm{XP}$ Investimentos & $\mathrm{R} \$ 18,90$ para ações operação normal & não cobra \\
\hline
\end{tabular}

Fonte: Elaborado pelo autor

Com base na tabela acima, nota-se que os valores cobrados de taxas de corretagem e de custódia de ações são maiores nas corretoras dos grandes bancos do que nas independentes. 
O Santander, por exemplo, cobra $\mathrm{R} \$ 30,63$ mensais pela custódia de ações, o que contrasta com o custo zero da maioria das corretoras independentes. Quanto aos valores referentes à corretagem também existem diferenças, com a possibilidade de não ser cobrado em determinadas corretoras independentes, como a Clear DTVM.

Outro fato a ser destacado, é que desde meados do ano passado, alguns bancos, inclusive os grandes analisados, começaram a zerar as taxas para aplicações no Tesouro Direto e outras aplicações de renda fixa como já faziam as Corretoras há alguns anos.

Comparando o número de clientes e o valor sob custódia nas Corretoras independentes, de 2016 e 2019, nota-se que ambos os valores cresceram, como mostra a tabela abaixo, mostrando um crescimento das Corretoras Independentes.

Tabela 2 - Clientes Ativos x Valor Sob Custódia nas Corretoras Independentes

\begin{tabular}{|c|c|c|c|c|}
\hline & \multicolumn{2}{|c|}{ Clientes Ativos } & \multicolumn{2}{|c|}{$\begin{array}{c}\text { Valor sob Custódia } \\
\text { R\$ }\end{array}$} \\
\hline & 2016 & 2019 & 2016 & 2019 \\
\hline Ativa Investimentos & $5 \mathrm{mil}$ & $21 \mathrm{mil}$ & 4,5 bilhões & 6 bilhões \\
\hline Easynvest & $170 \mathrm{mil}$ & $700 \mathrm{mil}$ & $\begin{array}{c}11,5 \\
\text { bilhões }\end{array}$ & 15 bilhões \\
\hline XP Investimentos & $750 \mathrm{mil}$ & $\begin{array}{l}1,25 \\
\text { milhão }\end{array}$ & \begin{tabular}{|l|}
170 \\
bilhões
\end{tabular} & $\begin{array}{c}250 \\
\text { bilhões }\end{array}$ \\
\hline
\end{tabular}

Fonte: Elaborado pelo autor

\subsubsection{Rentabilidade das Carteiras Sugeridas}

No referencial teórico, a variedade de produtos e a rentabilidade foram destacadas como fatores importantes para diferenciar as corretoras ligadas aos bancos das independentes. Normalmente, os grandes bancos privilegiam produtos próprios, enquanto as corretoras independentes oferecem produtos e fundos de diferentes gestores. Com isso, nas corretoras independentes tem-se uma diversidade muito maior de opções para investir, com possibilidade de maior rentabilidade.

$\mathrm{Na}$ análise feita nas carteiras de ações sugeridas pela corretoras independentes, notase, como mostrado no gráfico abaixo, que a maioria das corretoras independentes analisadas tiveram rentabilidade maior que o índice lbovespa, principal indicador de desempenho das ações negociadas na B3. A exceção foi a Ativa Investimentos, que mesmo assim, teve a rentabilidade da carteira sugerida superior a carteira sugerida pelas corretoras dos grandes bancos. 
Tabela 3 - Rentabilidade Carteira de ações Instituições Financeiras

\begin{tabular}{|l|c|}
\hline \multicolumn{1}{|c|}{ Corretoras } & Rentabilidade 2019 \\
\hline XP Investimentos & $25,50 \%$ \\
\hline Rico & $24,90 \%$ \\
\hline Ibovespa & $21,25 \%$ \\
\hline Ativa Investimentos & $19,68 \%$ \\
\hline Bradesco & $18,60 \%$ \\
\hline Santander & $17,45 \%$ \\
\hline Itaú Corretora & Não encontrado \\
\hline Easynvest & Não encontrado \\
\hline Clear Corretora & Não encontrado \\
\hline
\end{tabular}

Fonte: Elaborado pelo autor

O buscador de investimentos Yubb (2019) lançou há alguns anos, uma plataforma na qual os próprios investidores avaliam as empresas em diversas categorias, como atendimento, custos, taxas e rentabilidade. A avaliação das corretoras, feita este ano, tendo como nota mínima 1 e máxima 5 , feita pelos próprios clientes, demonstrou que as corretoras independentes são mais bem avaliadas do que as corretoras ligadas a bancos comerciais, como mostra a tabela em sequência:

Tabela 4 - Avaliação Instituições Financeiras

\begin{tabular}{|l|c|}
\hline \multicolumn{1}{|c|}{ Instituição financeira } & Nota \\
\hline Ativa & 4,18 \\
\hline Rico & 4,11 \\
\hline Clear Corretora & 4,06 \\
\hline Easynvest & 4,03 \\
\hline XP Investimentos & 3,93 \\
\hline Santander Corretora & 3,17 \\
\hline Itaú Corretora & 2,92 \\
\hline Bradesco Corretora & 2,44 \\
\hline
\end{tabular}

Fonte: Elaborado pelo autor

\subsection{Descrição da amostra e do perfil dos respondentes}

Dos 127 respondentes, 56\% tem até 25 anos de idade, $11 \%$ tem entre 26 e 40 anos, $31 \%$ tem entre 41 e 64 anos e apenas 3\% tem idade acima de 65 anos. Com relação a escolaridade, $42 \%$ possui graduação incompleta, 35\% graduação completa e 19\% pósgraduação. Com relação a renda mensal, $25 \%$ são considerados das classes $D, 39 \%$ são da classe $\mathrm{C}, 13 \%$ da classe $\mathrm{B}$ e $23 \%$ da classe $\mathrm{A}$ de renda. 
Tabela 5 - Respondentes por faixa etária

\begin{tabular}{|l|l|l|}
\hline \multicolumn{2}{|c|}{127} \\
$\begin{array}{c}\text { Total de respondentes } \\
\text { respondentes } \\
\text { por faixa de } \\
\text { idade }\end{array}$ & $\begin{array}{c}\text { Número de } \\
\text { por faixa de } \\
\text { idade }\end{array}$ \\
\hline $56 \%$ & 71 & Até 25 anos \\
$11 \%$ & 14 & Entre 26 e 40 anos \\
$30 \%$ & 38 & Entre 41 e 64 anos \\
$3 \%$ & 4 & Mais de 65 anos \\
\hline
\end{tabular}

Fonte: Elaborado pelo autor

Tabela 6 - Respondentes por faixa etária, renda e escolaridade

\begin{tabular}{|c|c|c|c|c|c|}
\hline \multicolumn{6}{|c|}{ Ensino Médio Completo } \\
\hline & Até $R \$ 2.000,00$ & \multicolumn{4}{|c|}{ De $\mathrm{R} \$ 2.000,00$ a $\mathrm{R} \$ 10.0$ De $\mathrm{R} \$ 10.000,00$ Acima de $\mathrm{R} \$ 20.000,00$} \\
\hline Até 25 anos & & 2 & 2 & 0 & 0 \\
\hline De 26 e 40 anos & & 0 & 0 & 0 & 0 \\
\hline De 41 e 64 anos & & 0 & 0 & 0 & 2 \\
\hline 65 anos ou mais & & 0 & 0 & 0 & 0 \\
\hline \multicolumn{6}{|c|}{ Graduação Incompleta } \\
\hline & Até $\mathrm{R} \$ 2.000,00$ & \multicolumn{4}{|c|}{ De $R \$ 2.000,00$ a $R \$ 10.0$ De $R \$ 10.000,00$ Acima de $R \$ 20.000,00$} \\
\hline Até 25 anos & & 23 & 21 & 0 & 2 \\
\hline De 26 e 40 anos & & 2 & 2 & 0 & 0 \\
\hline De 41 e 64 anos & & 0 & 0 & 0 & 2 \\
\hline 65 anos ou mais & & 0 & 0 & 2 & 0 \\
\hline \multicolumn{6}{|c|}{ Graduação Completa } \\
\hline & Até $R \$ 2.000,00$ & \multicolumn{4}{|c|}{ De $\mathrm{R} \$ 2.000,00$ a $\mathrm{R} \$ 10.0$ De $\mathrm{R} \$ 10.000,00$ Acima de $\mathrm{R} \$ 20.000,00$} \\
\hline Até 25 anos & & 4 & 13 & 2 & 0 \\
\hline De 26 e 40 anos & & 0 & 2 & 0 & 4 \\
\hline De 41 e 64 anos & & 0 & 4 & 7 & 9 \\
\hline 65 anos ou mais & & 0 & 0 & 2 & 0 \\
\hline \multicolumn{6}{|c|}{ Pós-graduação } \\
\hline & Até $R \$ 2.000,00$ & \multicolumn{4}{|c|}{ De $\mathrm{R} \$ 2.000,00$ a $\mathrm{R} \$ 10.0$ De $\mathrm{R} \$ 10.000,00$ Acima de $\mathrm{R} \$ 20.000,00$} \\
\hline Até 25 anos & & 0 & 2 & 0 & 0 \\
\hline De 26 e 40 anos & & 0 & 2 & 0 & 2 \\
\hline De 41 e 64 anos & & 0 & 1 & 4 & 9 \\
\hline 65 anos ou mais & & 0 & 0 & 0 & 0 \\
\hline
\end{tabular}

Fonte: Elaborado pelo autor

\subsubsection{Nível de Conhecimento em investimentos}

Dentre os respondentes, $65 \%$ tem o hábito de investir. Destes, a maioria é jovem, com menos de 25 anos (39 respondentes), porém os indivíduos de 41 a 64 anos se mostraram os mais conscientes sobre investir seu dinheiro, uma vez que $84 \%$ deles (32 pessoas) investem, enquanto apenas 6 deles não investem (16\%). Quanto a análise do conhecimento em investimentos, a minoria, ou seja, 18 pessoas (14\% dos respondentes) consideraram 
possuir conhecimento avançado. Dos demais, a grande maioria dos respondentes $(36 \%$ ou 46 pessoas) tem conhecimento básico e 29\% (37 pessoas) disseram ter conhecimento mediano sobre investimentos.

Quanto ao principal objetivo ao investir, 47\% investe para acumular ganhos acima da média de mercado, 39\% preservar seu capital e 14\% ter alta valorização de seus investimentos, mesmo correndo mais risco, o que nos demonstra uma tendência das pessoas a investirem em aplicações um pouco mais arriscadas para ganhar mais que a taxa CDI ou qualquer outra taxa de benchmark do mercado (IGP-M, IPCA, Ibovespa).

Quando se relaciona o principal objetivo ao investir e o tempo que pretendem manter seus investimentos, a opção de mais de 5 anos foi a mais escolhida. E a relação entre o objetivo ao investir e a decisão tomada se as ações do respondente tivessem uma desvalorização de $20 \%$, mostrou que a maioria dos que estão dispostos a correr mais riscos, comprariam mais ações, compatível com um perfil de risco arrojado.

Analisando as respostas do principal objetivo ao investir, tempo que pretendem manter seus investimentos, atitude tomada diante de uma desvalorização das ações com a carteira montada pelos respondentes traçou-se o perfil de risco dos mesmos como mostrado na tabela abaixo:

Tabela 7 - Perfil de Risco dos respondentes

\begin{tabular}{|ll|}
\hline \multicolumn{2}{|c|}{ Perfil de Risco } \\
Perfil Arrojado & 75 \\
Perfil Moderado & 19 \\
Perfil Conservador & 32 \\
\hline
\end{tabular}

Fonte: Elaborado pelo autor

Quando comparamos o nível de conhecimento em finanças autodeclarado com os objetivos na hora de investir, nota-se que quanto maior o conhecimento sobre investimentos, mais a pessoa está disposta a correr algum risco para obter maiores retornos. Em contrapartida, com nível básico de conhecimento o maior objetivo ao investir é preservar o capital, mostrando um perfil mais conservador.

Tabela 8 - Nível de Conhecimento x Objetivo ao investir

\begin{tabular}{|c|c|c|c|c|}
\hline Objetivo & Não tenho conhecimento & Básico & Mediano & Avançado \\
\hline $\begin{array}{l}\text { Ter alta valorização de seus } \\
\text { investimentos, mesmo correndo mais } \\
\text { risco }\end{array}$ & 4 & 2 & 5 & 7 \\
\hline $\begin{array}{l}\text { Acumular ganhos acima da média do } \\
\text { mercado }\end{array}$ & 12 & 14 & 23 & 11 \\
\hline Preservar seu capital & 11 & 30 & 9 & 0 \\
\hline
\end{tabular}

Fonte: Elaborado pelo autor 
Na pesquisa realizada, dos 18 respondentes com conhecimento avançado, 11 querem acumular ganhos acima da média do mercado e 7 almejam ter uma alta valorização de seus investimentos, mostrando um perfil moderado ou arrojado.

\subsubsection{Tipo de Instituição financeira para investir}

Quanto ao tipo de instituição financeira escolhida para investir, 52\% escolheram corretoras independentes, $19 \%$ bancos comerciais e $29 \%$ corretoras ligadas aos bancos.

Quando comparamos o tipo da instituição financeira, com a carteira de investimentos dos respondentes, observa-se que os que têm um perfil mais conservador tendem a utilizar mais os bancos comerciais, enquanto os que têm um perfil moderado ou agressivo já possuem ampla preferência pelas corretoras independentes, conforme demonstrado na tabela abaixo:

Tabela 9 - Tipo de Instituição financeira x Perfil de Investimento

\begin{tabular}{|lrrr|}
\hline & Perfil Arrojado & Perfil Moderado & Perfil Conservador \\
Corretoras Independentes & 46 & 10 & 9 \\
Bancos Comerciais & 5 & 2 & 17 \\
Corretoras ligadas aos bancos & 24 & 7 & 6 \\
\hline
\end{tabular}

Fonte: Elaborado pelo autor, a partir do questionário (2019)

Quanto a relação nível de conhecimento e tipo de instituição financeira para investir, nota-se que as corretoras independentes aparecem como preferência para os que detém maior conhecimento sobre investimentos. Das 46 pessoas com conhecimento básico, apenas 7 escolheram as corretoras independentes como principal instituição para aplicar seu dinheiro.

Tabela 10 - Nível de Conhecimento x Tipo de Instituição Financeira

\begin{tabular}{|lrrrr|}
\hline & Básico & \multicolumn{5}{c|}{ Mediano Avançado Nenhum } \\
Corretoras Independentes & 7 & 21 & 13 & 2 \\
Bancos Comerciais & 14 & 7 & 1 & 20 \\
Corretoras ligadas aos bancos & 25 & 8 & 4 & 5 \\
\hline
\end{tabular}

Fonte: Elaborado pelo autor, a partir do questionário (2019)

Quando perguntados por que escolheram este tipo de instituição, taxas menores apareceram como primeira opção, citada por $43 \%$ dos respondentes, variedade de produtos 
apareceu em segundo, escolhido por $32 \%$ dos respondentes e rentabilidade como a terceira opção, escolhida por $25 \%$ dos respondentes.

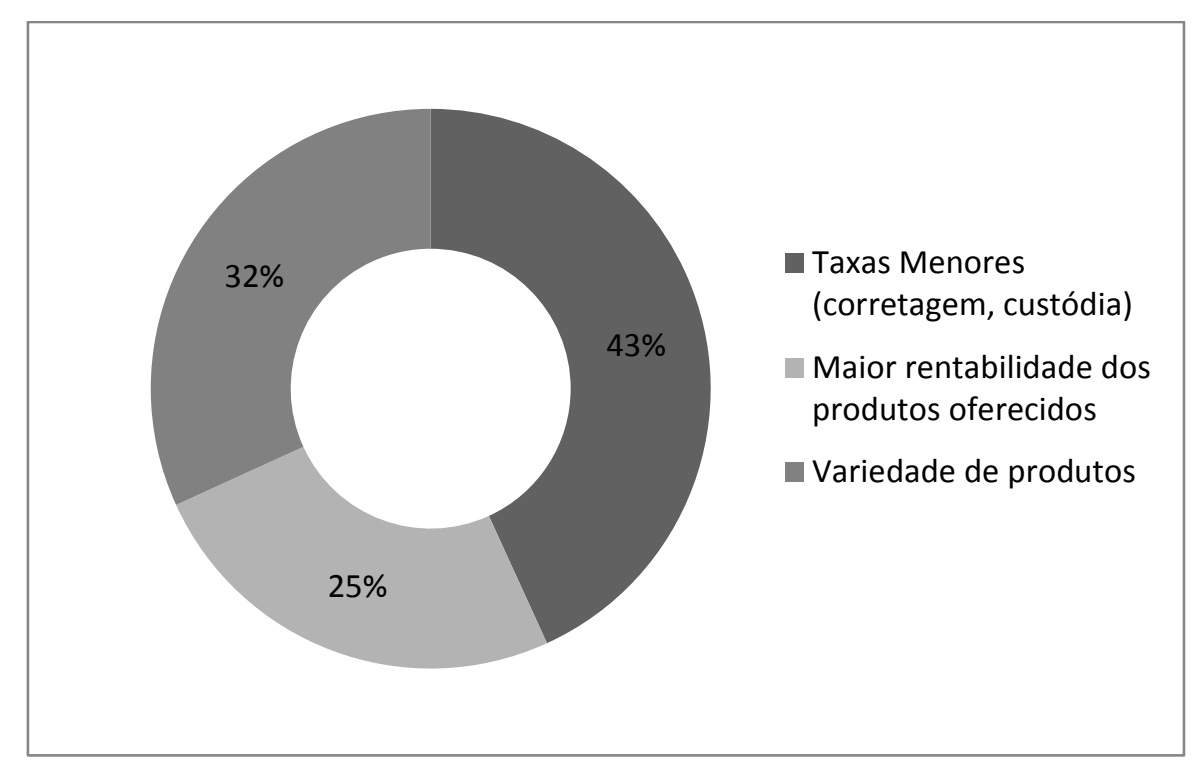

Gráfico 3 - Motivos escolha Instituição Financeira para investir.

Fonte: Elaborado pelo autor, a partir do questionário (2019)

\subsubsection{Rentabilidade Carteira dos respondentes}

Com base no perfil de risco dos respondentes, montou-se uma carteira hipotética, mostrada abaixo, baseada na carteira sugerida no referencial teórico. Para rentabilidade dos produtos utilizou-se as rentabilidades médias de produtos oferecidos pela XP Investimentos e quanto ao prazo dos títulos de renda fixa e CDB, optou-se pelo prazo de 5 anos, pois em todos os níveis de conhecimento a opção de manter seus investimentos por mais de 5 anos, foi a mais escolhida. 
Tabela 11 - Rentabilidade Carteiras Corretoras Independentes

\begin{tabular}{|c|c|c|}
\hline Perfil Conservador & Alocação & $\begin{array}{c}\text { Rentabilidade } \\
\text { Mês } \\
\text { setembro/2019 }\end{array}$ \\
\hline Renda Fixa & $85 \%$ & \\
\hline CDB pós-fixado - 5 anos & $80 \%$ & $0,54 \%$ \\
\hline CDB pré-fixado - 5 anos & $5 \%$ & $0,18 \%$ \\
\hline \multicolumn{3}{|l|}{ Multimercado } \\
\hline Renda Fixa & $15 \%$ & $1,62 \%$ \\
\hline Rentabilidade Carteira & & $0,68 \%$ \\
\hline Perfil Moderado & Alocação & $\begin{array}{c}\text { Rentabilidade } \\
\text { Mês } \\
\text { setembro/2019 }\end{array}$ \\
\hline Renda Fixa & $70 \%$ & \\
\hline Fundo RF pós-fixado 5 anos & $60 \%$ & $0,68 \%$ \\
\hline CDB pós-fixado - 5 anos & $10 \%$ & $0,54 \%$ \\
\hline \multicolumn{3}{|l|}{ Multimercado } \\
\hline Renda Fixa & $15 \%$ & $1,62 \%$ \\
\hline Renda Variável & $5 \%$ & $1,86 \%$ \\
\hline Ações & $10 \%$ & $2,30 \%$ \\
\hline Rentabilidade Carteira & & $1,03 \%$ \\
\hline Perfil Arrojado & Alocação & $\begin{array}{c}\text { Rentabilidade } \\
\text { Mês } \\
\text { setembro/2019 }\end{array}$ \\
\hline Renda Fixa & $50 \%$ & \\
\hline Fundo RF pós-fixado 5 anos & $40 \%$ & $0,68 \%$ \\
\hline CDB pós-fixado - 5 anos & $10 \%$ & $0,54 \%$ \\
\hline \multicolumn{3}{|l|}{ Multimercado } \\
\hline Renda Fixa & $15 \%$ & $1,62 \%$ \\
\hline Renda Variável & $15 \%$ & $1,86 \%$ \\
\hline Ações & $20 \%$ & $2,30 \%$ \\
\hline Rentabilidade Carteira & & $1,29 \%$ \\
\hline
\end{tabular}

Fonte: Elaborado pelo autor

Em todos os perfis de risco, a rentabilidade seria maior do que a do CDI (Certificado de Depósito Interbancário), usado como referência para a maioria das aplicações de renda fixa. No mês de setembro/2019 o valor deste índice foi de 0,4638\%.

As carteiras de investimentos das corretoras estão de acordo com a composição das carteiras apresentadas no referencial teórico. 


\section{Conclusão}

Hoje as corretoras dos grandes bancos ainda possuem mais clientes do que as Corretoras Independentes. O estudo procurou avaliar o crescimento das corretoras independentes no mercado brasileiro. Vários aspectos foram pesquisados como as taxas cobradas, número de clientes, serviços, rentabilidade e diversidade de produtos. Além disso, buscou-se avaliar os tipos de perfil dos investidores, os produtos financeiros sugeridos para cada um deles e a rentabilidade dos mesmos.

O questionário apontou que as pessoas com maior conhecimento financeiro são as de perfil moderado e arrojado, as quais preferem as corretoras independentes na hora de investir. São pessoas dispostas a correr mais risco, que buscam melhores retornos.

As corretoras dos grandes bancos oferecem, na maioria das vezes, produtos próprios, tendo menos opções de investimento para oferecer. Já as corretoras independentes oferecem produtos de diversos emissores, inclusive de bancos menores, tendo mais opções de investimento para oferecer, com retornos maiores.

Quanto aos custos, observou-se que as taxas cobradas pelas corretoras independentes são menores do que as cobradas pelas corretoras ligadas aos bancos comerciais e que isso é um fator importante na hora de escolher a corretora para investir.

Nota-se que as corretoras independentes estão aumentando a sua participação e que isso vem sendo percebido pelos grandes bancos. As taxas cobradas são um atrativo na hora de investir e por esse motivo as corretoras dos grandes bancos, tentando ficar mais competitivas, a partir do início deste ano, deixaram de cobrar taxa administrativa sobre Letra do Tesouro Direto. Além das letras, os custos relacionados às operações de títulos de renda fixa também foram zerados.

Quando se avaliam os números apresentados nos sites das corretoras independentes estudadas, verifica-se que houve um aumento no número de clientes ativos e no valor sob custódia das mesmas nos últimos anos.

Quanto à rentabilidade, as carteiras de ações sugeridas pelas corretoras independentes analisadas neste estudo, tiveram resultados maiores que o índice lbovespa. $\mathrm{E}$, quanto aos produtos de renda fixa, a rentabilidade deles nas carteiras sugeridas pelas corretoras independentes ficaram maiores que o CDI.

As corretoras independentes estão aumentando sua participação no mercado, com custos menores, maiores retornos, e maiores opções de investimentos. Esse crescimento e popularização das corretoras independentes pôde ser observado, também, no questionário 
realizado, onde nota-se a preferência dos jovens pelas corretoras independentes (especialmente os de até 25 anos).

Estudos futuros podem acompanhar o movimento das corretoras independentes de zerarem suas taxas e da relação do aumento da educação financeira dos investidores com o crescimento das corretoras independentes. 


\section{Referências}

Anbima, Investimentos dos brasileiros alcançam $\mathbf{R}$ 2,98 trilhões no primeiro trimestre. Disponível em <http://www.anbima.com.br/pt_br/noticias/investimentos-dos-brasileirosalcancam-r-2-98-trilhoes-no-primeiro-trimestre.htm>. Último acesso em: 04 de jun. 2019.

Anbima, Menos da metade dos brasileiros têm dinheiro aplicado em produtos financeiros. Disponível em <http://www.anbima.com.br/pt_br/noticias/menos-da-metadedos-brasileiros-tem-dinheiro-aplicado-em-produtos-financeiros.htm>. Último acesso em: 04 de jun 2019.

Anbima, Raio X do investidor brasileiro. Disponível em http://www.anbima.com.br/pt_br/ especial/raio-x-do-investidor-2018.htm>. Último acesso em: 29 de mai 2019.

ASSAF NETO, Alexandre. Mercado Financeiro. 13. ed. São Paulo: Atlas, 2015.

Banco Central do Brasil, O que são a corretora e a distribuidora de títulos e de valores mobiliários?. Disponível em https://www.bcb.gov.br/acessoinformacao. Último acesso em 19 de jun. de 2019.

Bancodata. Ativa Investimentos. Disponível em: <https://bancodata.com.br/relatorio/ativasa-investimentos-cctvm/>. Último acesso em 17 de out. de 2019.

Bancodata. Easynvest. Disponível em: https://bancodata.com.br/relatorio/easynvest-titulocv-sa>. Último acesso em 17 de out. de 2019.

Bancodata. XP Investimentos. Disponível em: < https://bancodata.com.br/relatorio/xpinvestimentos-cctvm-sa>. Último acesso em 17 de out. de 2019.

Banco Santander, Investimentos e Previdência. Disponível em: <https://www.santander.com.br/investimentos-e-previdencia>. Acesso em: 13 set. 2019. 
B3, Bolsa brasileira atinge 1,1 milhão de investidores em maio, diz B3. Disponível em https://g1.globo.com/economia/noticia/2019/06/10/bolsa-brasileira-atinge-11-mi-deinvestidores-em-maio-diz-b3.ghtml. Último acesso em: 27 de jun. 2019.

B3, Sobre o PQO. Disponível em <http://www.b3.com.br/pt_br/b3/qualificacao-egovernanca/selos-pqo/sobre-o-pqo.htm>. Último acesso em: 12 de set. de 2019.

Blog.RICO, Tipos de investimentos. Disponível em: < https://blog.rico.com.vc/tipos-deinvestimentos>. Último acesso em 02 de dez. de 2019.

BONA, André. Perfil do Investidor: o que é e como funciona? 2017. Blog Renda Fixa. Disponível em: <http://www.blog.rendafixa.rocks/investimentos/perfil-do-investidor-o-que-ee-como-funciona/>. Último acesso em: 22 jun. 2019.

BRASIL, Comissão de Valores Mobiliários. Mercado de Valores Mobiliários Brasileiro. 3ed. Rio de Janeiro: Comissão de Valores Mobiliários, 2014.

Cutait, Beatriz. Com captação maior que a dos bancos gestoras independentes devem crescer com fundos imobiliários e previdência. Disponível em:

$<$ https://www.infomoney.com.br/onde-investir/fundos-de-investimento/noticia /8444216/comcaptacao-maior-que-a-dos-bancos-gestoras-independentes-devem-crescer-com-fundosimobiliarios-e-previdencia>. Acesso em: 04 set. 2019.

CVM, Cenário da poupança e dos investimentos dos brasileiros. Disponível em <http://www.cvm.gov.br/export/sites/cvm/menu/investidor/estudos/pesquisas/ 20181002_estudo_spc_cenario_da_poupanca_e_dos_investimentos_dos_brasileiros.pdf>. Último acesso em 29 de mai. 2019.

CVM, Portal do Investidor - Princípios do Investimento. Disponível em: $<$ https://www.investidor.gov.br/menu/primeiros_passos/principios_investimento.html>. Último Acesso em 20 de ago. de 2019.

CVM, Sobre a CVM. Disponível em <http://www.cvm.gov.br/menu/acesso_ informacao/institucional/sobre/cvm.html>. Último acesso em 29 de mai. de 2019. Easynvest. Nossos Resultados. Disponível em < https://www.easynvest.com.br/nossosresultados.html>. Último acesso em 03 de out. 2019. 
Exame. Site mostra as melhores corretoras e bancos para investir. Disponível em: https://exame.abril.com.br/seu-dinheiro/site-mostra-as-melhores-corretoras-e-bancos-parainvestir/. Acesso em: 03 out. 2019.

FORTUNA, Eduardo. Mercado Financeiro: Produtos e Serviços. 19 ed. Rio de Janeiro: Qualitymark editora, 2014.

GIL, Antonio Carlos. Como elaborar projetos de pesquisa. 4. ed. São Paulo: Atlas, 2008.

LULA MOTA, Arthur. O que é a CVM e qual a sua função. São Paulo, 27 de fev. 2018. Disponível em < https://maisretorno.com/blog/o-que-e-a-cvm> . Último acesso em: 19 de jun. de 2019.

Mallmann, Tatiana. O Que São e Como Funcionam as Corretoras de Valores? Disponível em < https://londoncapital.com.br/blog/o-que-sao-e-como-funcionam-as-corretoras-devalores/>. Último acesso em 26 de jun. de 2019.

Mallmann, Tatiana. Corretora de Valores - Como Escolher a Melhor para seus Investimentos? Disponível em https://londoncapital.com.br/blog/como-escolher-corretorade-valores/>. Último acesso em 10 de set. de 2019.

Martins, Danilo. Vai começar a investir? Saiba como escolher uma corretora. Disponível em < https://valorinveste.globo.com/produtos/servicos-financeiros/noticia/2019/05/09/vaicomecar-a-investir-saiba-como-escolher-uma-corretora.ghtml>. Último acesso em 02 de dez. de 2019.

PAVINI, Ângelo. Globo compra participação na Órama e entra no segmento de aplicações financeiras. Disponível em: <https://moneytimes.com.br/globo-compraparticiacao-na-orama-e-entra-no-segmento-de-aplicacoes-financeiras/>. Acesso em: 30 jun. 2019.

PRODANOV, Cleber Cristiano; FREITAS, Ernani Cesar de. Metodologia do Trabalho Cientifico: Métodos e Técnicas da Pesquisa e do Trabalho Acadêmico. 2. ed. Novo Hamburgo: Universidade Feevale, 2013. Disponível em: 
<http://www.feevale.br/Comum/midias/8807f05a-14d0-4d5b-b1ad-1538f3aef538/Ebook\%20Metodologia\%20do\%20Trabalho\%20Cientifico.pdf>. Acesso em: 05 abr. 2019.

Proteste. PROTESTE divulga cinco dicas para escolher melhores opções de investimento. Disponível em <https://www.proteste.org.br/institucional/imprensa /pressrelease/2017/proteste-divulga-cinco-dicas-para-escolher-melhores-opcoes-de-investimento>. Acesso em: 03 out. 2019.

PEROVANO, D. G. Manual de metodologia científica: para segurança pública e defesa social. 1 ed. São Paulo: Jurua Editora, 2014.

Valor Econômico, Jovens ampliam participação na bolsa. Disponível em $<$ https://www.valor.com.br/financas/5277877/jovens-ampliam-participacao-na-bolsa>. Último acesso em 01 de jul. de 2019.

XP Investimentos. Carteiras Recomendadas. Disponível em <https://conteudos.xpi.com.br / carteiras-recomendadas/>. Último acesso em 31/10/2019.

Wawrzeniak ,Diego. Como escolher uma corretora de Valores. Disponível em: $<$ https://www.bussoladoinvestidor.com.br/escolher-uma-corretora-de-valores/>. Acesso em:13 set. 2019

WILTGEN, J. Você sabe o seu perfil de investidor? Conheça os 3 tipos. Genial Investimentos, 2016. Disponivel em: <https://www.genialinvestimentos.com.br /artigo/vocesabe-o-seu-perfil-de-investidorconheca-os>. Acesso em: 23 ago. 2019.

Yubb. Empresas de investimento avaliadas por investidores. Disponível em: <https://yubb.com.br/melhores-empresas-de- investimento ?utm_source=yubb_header.> Acesso em: 03 out. 2019. 


\section{Anexo 1 - Questionário}

Qual é a sua idade?

- Até 25 anos

- $\quad$ De 26 e 40 anos

- $C$ De 41 e 64 anos

- 65 anos ou mais

Qual a sua escolaridade?

- Ensino Fundamental Completo

- Ensino Médio Completo

- Graduação Incompleta

- G Graduação Completa

- $P$ Pós-graduação

Qual sua faixa de renda mensal média?

- Até $\mathrm{R} \$ 2.000,00$

- $D$ De $R \$ 2.000,00$ a $R \$ 10.000,00$

- $\mathrm{De} R \$ 10.000,00$ a $\mathrm{R} \$ 20.000,00$

- Acima de $\mathrm{R} \$ 20.000,00$

Você costuma investir seu dinheiro?

- $\bullet \operatorname{Sim}$

- C Não

Como você avalia seu conhecimento sobre investimentos?

- Não tenho conhecimento

- Básico

- C Mediano

- Avançado 
Qual seria seu objetivo principal ao investir?

- $\mathrm{C}$ Preservar seu capital

- Acumular ganhos acima da média do mercado

- Ter alta valorização de seus investimentos, mesmo correndo mais risco

Por quanto tempo você deseja(ria) manter seus investimentos?

- Menos de 1 ano

- De 1 a 3 anos

- $\mathrm{De} 3$ a 5 anos

- Mais de 5 anos

O que você faria se suas ações caíssem $20 \%$ ?

- $\mathrm{C}$ Venderia tudo

- $\mathrm{C}$ Venderia parte das ações

- Seguraria minhas ações

- Compraria mais ações

Qual(is) tipo(s) de instituição(ões) financeira(s) você prefere para aplicar seu dinheiro?

- $\Gamma$ Corretoras Independentes

- $\Gamma$ Corretoras ligadas aos bancos

- $\quad$ Bancos Comerciais

Por qual(is) motivo(s) você escolheu essa(s) instituição(ões)?

- $\Gamma$ Segurança

- $\square$ Comodidade (Já tinha conta anteriormente)

- Г Taxas menores (corretagem, custódia)

- $\quad$ Acessibilidade (Home broker e aplicativo de fácil uso)

- $\square$ Maior rentabilidade dos produtos oferecidos

- $\Gamma$ Variedade de produtos

- $\square$ Atendimento ao cliente diferenciado

Se você tem ou fosse montar sua carteira de investimentos, quantos \% do total da carteira alocaria em cada uma das opções abaixo? (preencha até completar 100\%)

\begin{tabular}{lll}
\hline \multicolumn{1}{l}{} & 0 & Poupança \\
- & 0 & Títulos públicos
\end{tabular} 
- $\begin{aligned} & 0 \\ & 0\end{aligned}$

- 0 Fundos de ações

- 0 Fundos multimercado

- 0 Ações

- 0 Nunca investi 